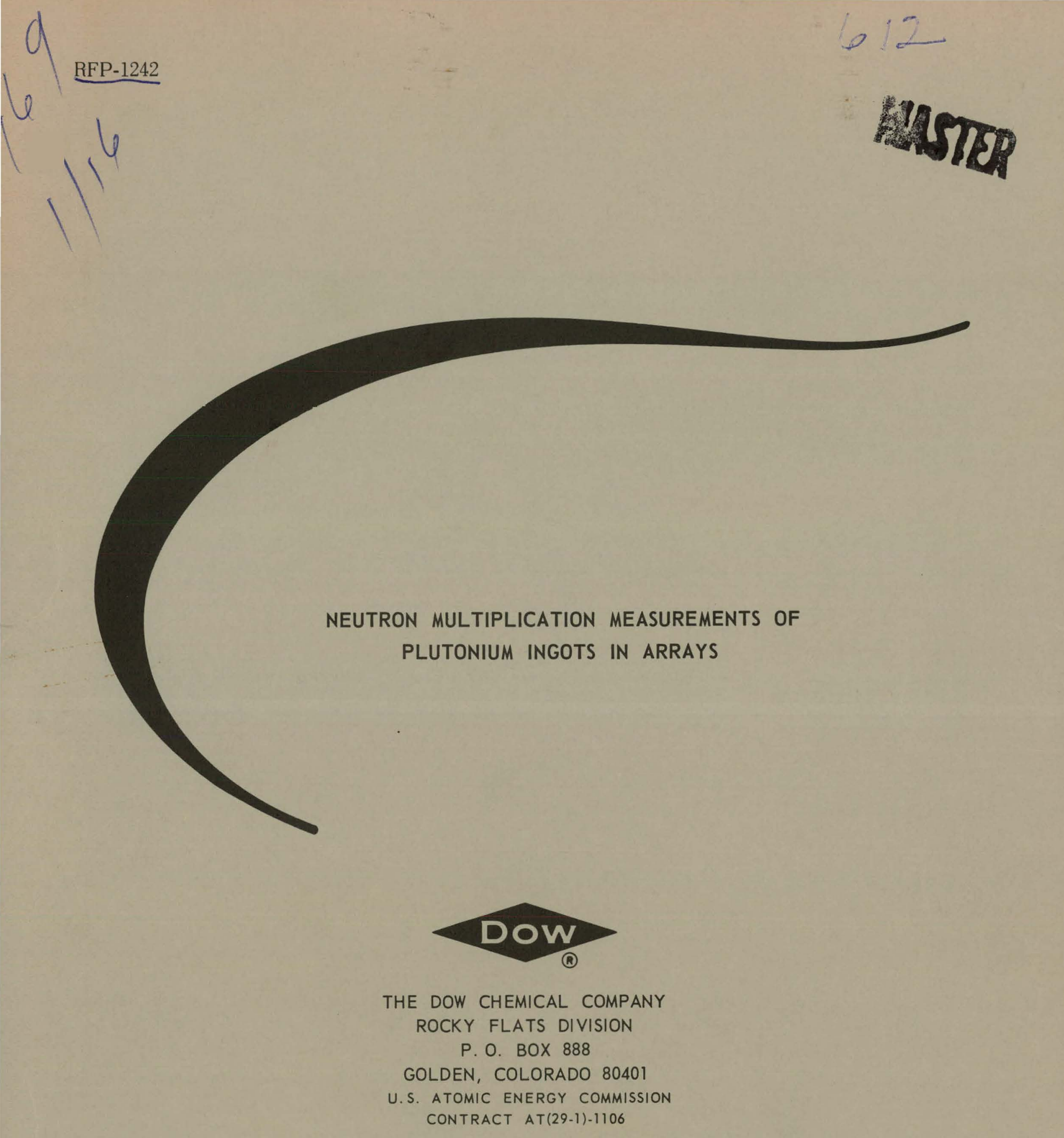




\section{DISCLAIMER}

This report was prepared as an account of work sponsored by an agency of the United States Government. Neither the United States Government nor any agency Thereof, nor any of their employees, makes any warranty, express or implied, or assumes any legal liability or responsibility for the accuracy, completeness, or usefulness of any information, apparatus, product, or process disclosed, or represents that its use would not infringe privately owned rights. Reference herein to any specific commercial product, process, or service by trade name, trademark, manufacturer, or otherwise does not necessarily constitute or imply its endorsement, recommendation, or favoring by the United States Government or any agency thereof. The views and opinions of authors expressed herein do not necessarily state or reflect those of the United States Government or any agency thereof. 


\section{DISCLAIMER}

Portions of this document may be illegible in electronic image products. Images are produced from the best available original document. 


\section{LEG A L NOTICE}

This report was prepared as an account of Government sponsored work. Neither the United States, nor the Commission, nor any person acting on behalf of the Commission:

A. Makes any warranty or representation, expressed or implied, with respect to the accuracy, completeness, or usefulness of the information contained in this report, or that the use of any information, apparatus, method, or process disclosed in this report may not infringe privately owned rights; or

B. Assumes any liabilities with respect to the use of, or for damages resulting from the use of any information, apparatus, method, or process disclosed in this report.

As used in the above, "person acting on behalf of the Commission" includes any employee or contractor of the Commission, or employee of such contractor, to the extent that such employee or contractor of the Commission, or employee of such contractor prepares, disseminates, or provides access to, any information pursuant to his employment or contract with the Commission, or his employment with such contractor.

Printed in the United States of America Available from

Clearinghouse for Federal Scientific and Technical Information

National Bureau of Standards, IT. S. Department of Commerce

Springfield, Virginia 22151

Price: Printed Copy $\$ 3.00$; Microfiche $\$ 0.65$ 


\title{
NEUTRON MULTIPLICATION MEASUREMENTS OF PLUTONIUM INGOTS IN ARRAYS
}

\author{
Donald R. Fergusan
}

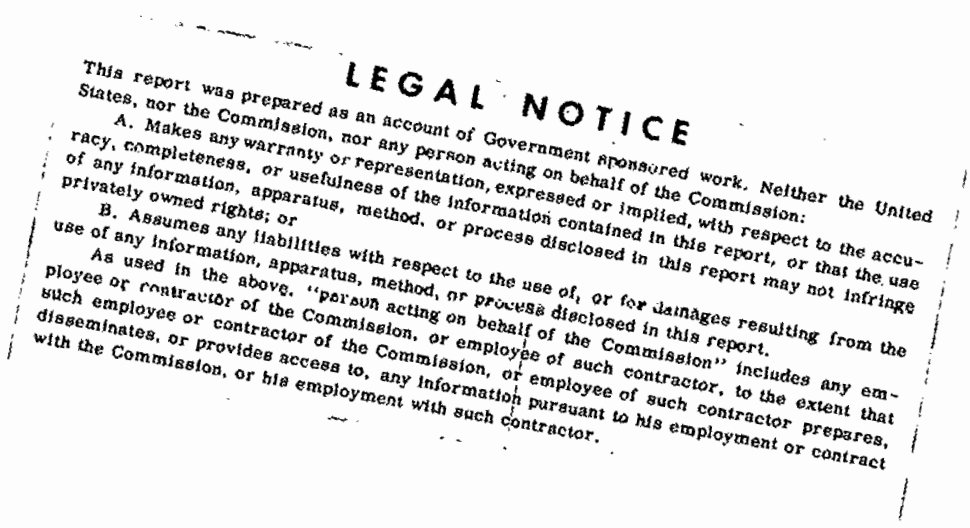

THE DOW CHEMICAL COMPANY

ROCKY FLATS DIVISION

P. O. BOX 888

GOLDEN, COLORADO 80401

U. S. ATOMIC ENERGY COMMISSION CONTRACT AT(29-1)-1106 
RFP-1242 


\section{CONTENTS}

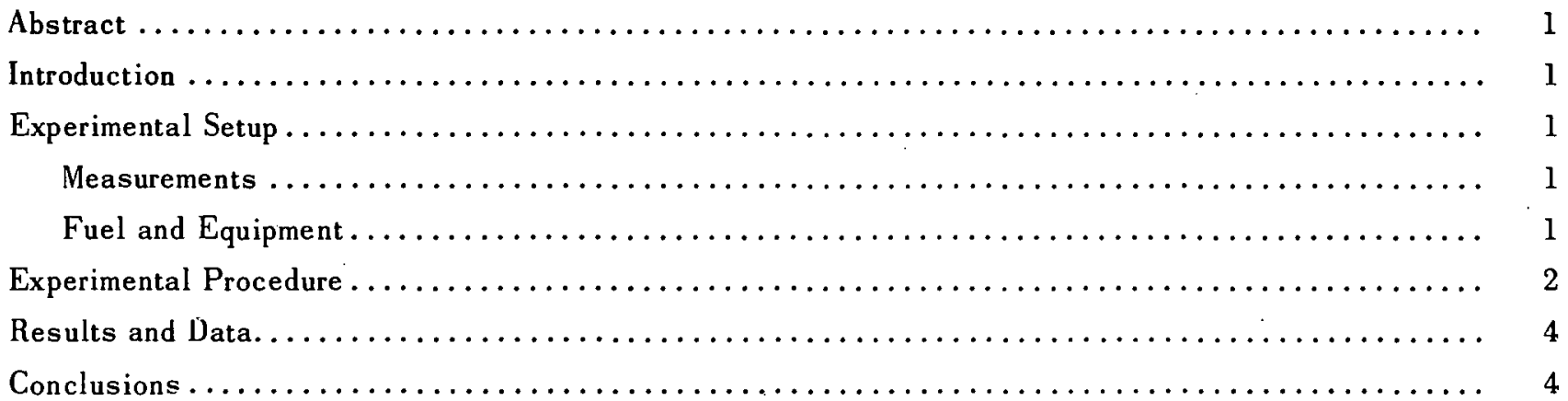




\title{
ACKNOWLEDGMENTS
}

\begin{abstract}
Appreciation is expressed to the following for work done in performing the reported measurements: H. Clark, H. W. King, R. J. Kosizek, D. Payne, W. R. Sheets, C. A. Stevens, and K. O. Zumwalt.
\end{abstract}




\title{
NEU'TRON MUL'IPLICATION MEASUREMENTS OF PLUTONIUM INGO'TS IN ARRAYS
}

\author{
Donald R. Ferguson
}

\begin{abstract}
Included in the report are a series of neutron multiplication measurements on partially moderated and partially reflected arrays of 55 gallon drums. Each drum contains a plutonium ingot of about 12 kilograms with a density of $\mathbf{1 5 . 8}$ grams per cubic centimeter.
\end{abstract}

\section{INTRODUCTION}

Two sets of neutron multiplication measurements were made for the dual purpose of examining the safety margin of the present mode of plutoniumingot storage which was based on calculations; and secondly to obtain data which could be used in developing safe storage rules, hopefully to increase current storage capabilities for the ingots.

\section{EXPERIMENTAL SETUP}

The first set of measurements was made in a high vault of 15 by 25 by 13.5 feet with thick concrete walls. A false floor was laid consisting of 4-inch thick solid concrete blocks. An opening was left in the center of the room to place two boron trifluoride $\left(\mathrm{BF}_{3}\right)$ counter tubes for permanently locating them beneath the center of the array as shown in Figure 1.

\section{Measurements:}

Measurements were made on three types of arrays in the vault:

1. A planar close-packed hexagonal array of 46 drums.

2. A two-layer high hexagonal array with 92 drums.

3. A three-wide by two-high hexagonal array around the perimeter of the vault with 136 drums.

\begin{abstract}
A second set of measurements nade in a tunnel connecting to the vault. The tunnel is 7.5 feet wide by 10 feet high by 225 feet long with thick concrete walls. Measurements were made also on three different arrays:
\end{abstract}

1. One row, two high by 23 drums long.

2. Two rows, two high by 23 drums long.

3. Three rows two high by 23 drums long.

Two $\mathrm{BF}_{3}$ counters were placed against the wall on the end of these arrays to minimize sourceeffect distortion of the reciprocal multiplication curves.

\section{Fuel and Equipment:}

The fuel used for the measurements was plutonium ingots having a density of 15.8 grams per cubic centimeter $\left(\mathrm{g} / \mathrm{cm}^{3}\right)$. The weight of the ingots varied from 11.4 minimum to 12.0 kilograms $(\mathrm{kg})$ maximum. The average weight of an ingot in the array was $11.8 \mathrm{~kg}$. : The ingot dimensions are approximately 10 by 12 by 0.4 inches thick. Each ingot was wrapped in a polyethylene bag and plastic tape which weighs about 2.5 pounds. ${ }^{1}$. The wrapped ingot is then contained in a 19-inch diameter by $2 \frac{3}{8}$-inch high film can.

The outside container is a 55 -gallon drum of 24 inch diameter by 35 inches high. A Fibre Pak $\circledast{ }^{2}$ which is a cardboard annulus having a 0.25 -inch wall thickness, 15-inch diameter, 16-inch height, and a weight of 7 pounds, is placed in the bottom of each 55-gallon drum. On top of the Fibre-Pak

\footnotetext{
If the plastic were distributed evenly around the ingot the thickness of the plastic would be about 0.2 inches.

${ }^{2}$ Continental Can Company, Inc., New York.
} 


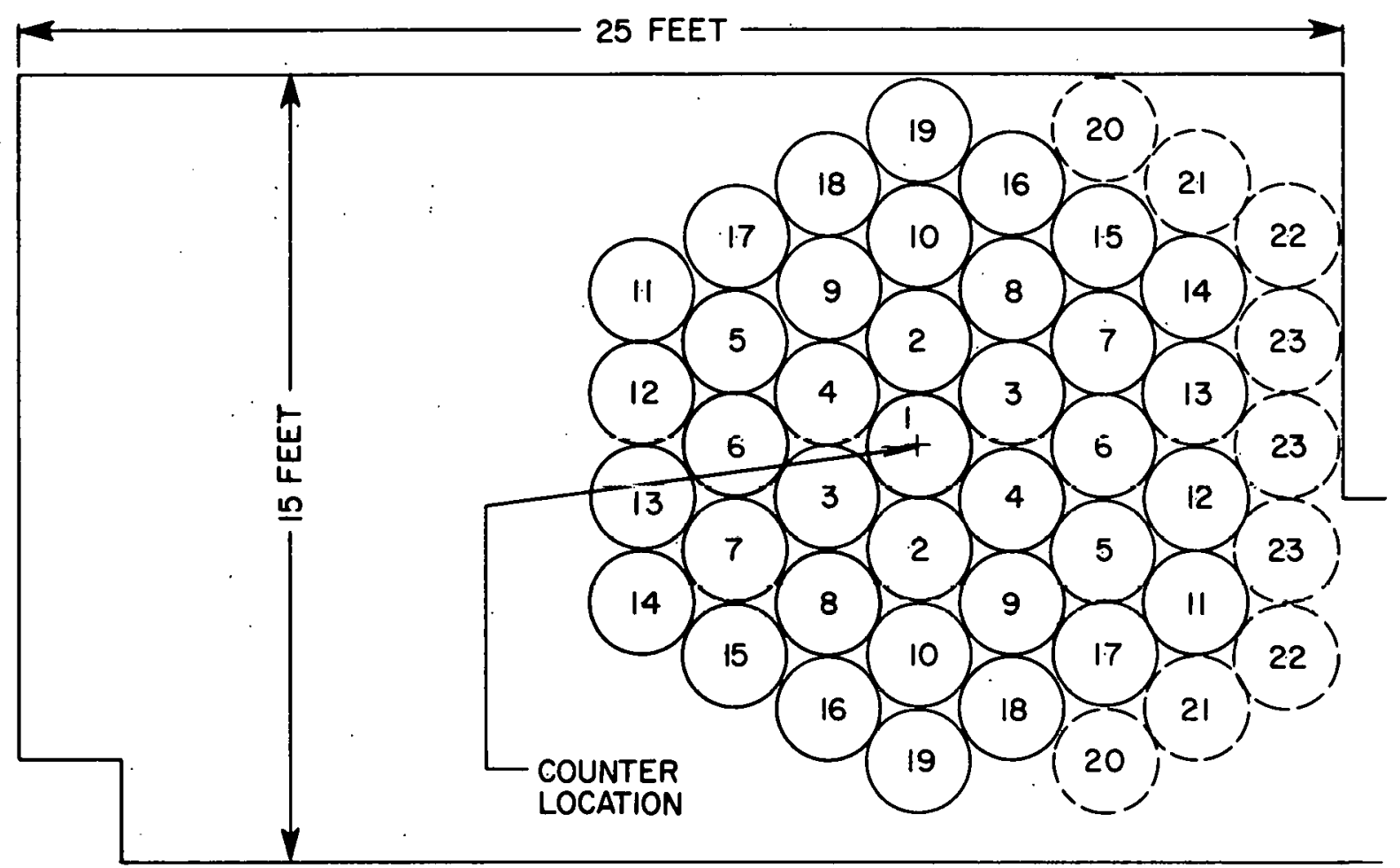

Legend

(1) - Numerals on drums indicate the sequence in which the drums were added to the array.

(20) - Drums added to only one side of array because of limiting dimensions of room.

The addition of these drums indicated that the array was close to being

infinite. Thus, the further addition of drums was unnecessary.

FIGURE 1. Diagram of First Array Measurement in the Room.

is placed the film can containing the ingot. On top of the film can, another Fibre-Pak spacer is placed which is 13.5 inches high and weighs 5 pounds. The drum cover is then sealed on the drum. When the drums were stacked, the ingots had a 35-inch minimum vertical ccnter-to-centcr separation.

The drums when placed together in a close-packed hexagonal array occupy an area lattice of 499 square inches and a lattice volume of 10.1 cubic feet. The plutonium density in the arrays was $0.041 \mathrm{~g} / \mathrm{cm}^{3}$.

\section{EXPERIMENTAL PROCEDURE}

In the first set of measurements, one drum from the center of the array was placed on the false concrete floor directly over the two detectors. A 60-second count was taken and used as a 


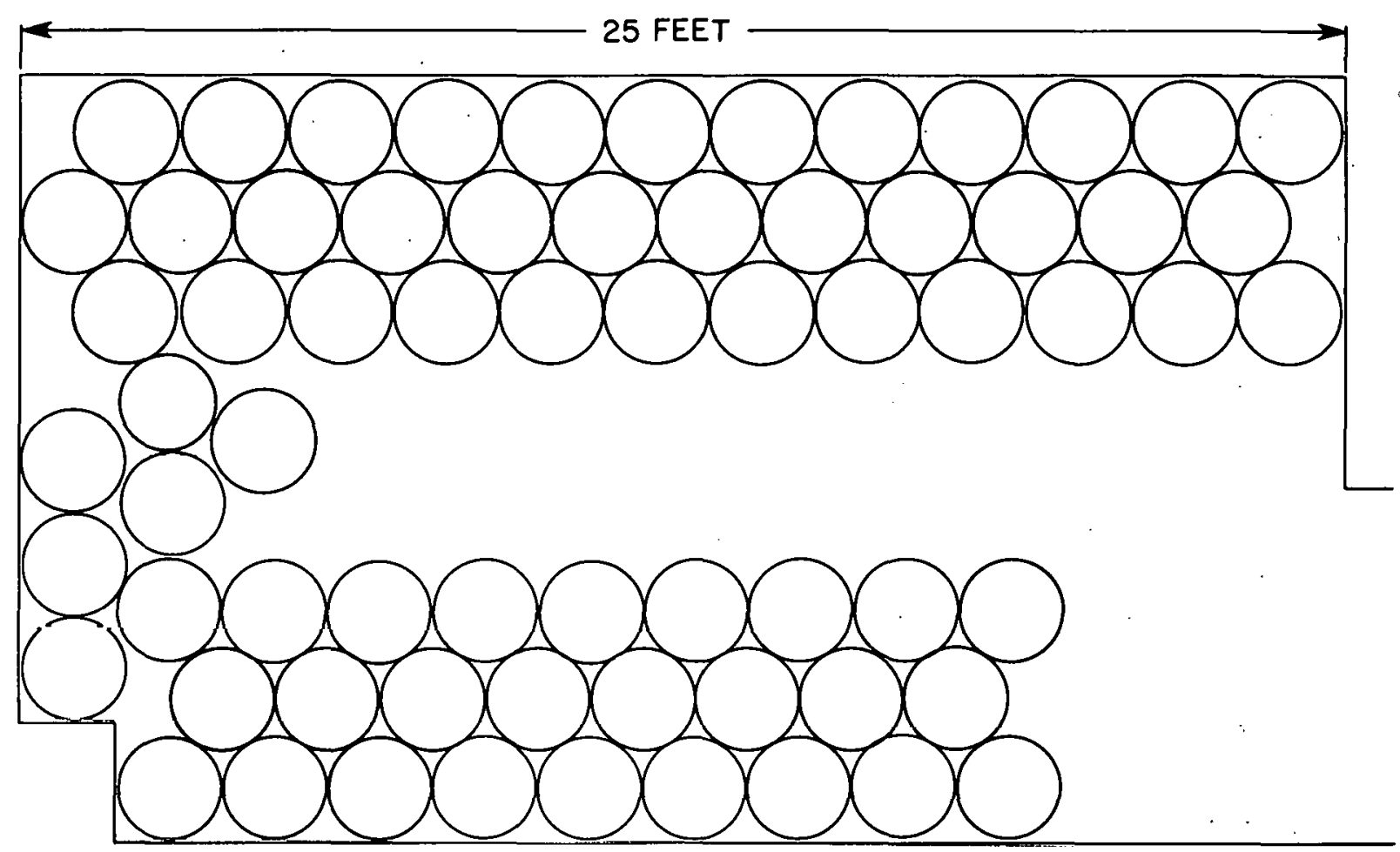

FIGURE 2. Diagram of Array Measurement in the Room.

base count for calculating the reciprocal neutron multiplication for the rest of the measurements.

Additional drums were added two at a time on opposite sides of the center drum to maintain a symmetric hexagonal array. A 60 -second count was taken and the reciprocal multiplication ( $1 / \mathrm{M})$ data were calculated and plotted after each fuel addition.

After assembling the 37-drum hexagonal array (Figure 1) additional drums could only be added to three sides of the array because the array blocked off the other side of the room.

The drums were then arranged in an array, 3-drums wide and 2-layers high around the perimeter of the room as noted in Figure 2 and were found to be less reactive than the array in Figure 1.

In the set of measurements done in the tunnel, the detectors were placed on the floor at the end of the array (Figure 3). Drums were added in a row along the tunnel wall and counts were taken periodically. After 15 drums were placed in a.row; the $1 / \mathrm{M}$ plot clearly became asymptotic. The array was extended to 23 drums in length just to make certain the plot. stayed flat.

Then a second layer of drums was added to the first row in a similar manner. A second row was started in the same manner as the first and similarly a third row. 


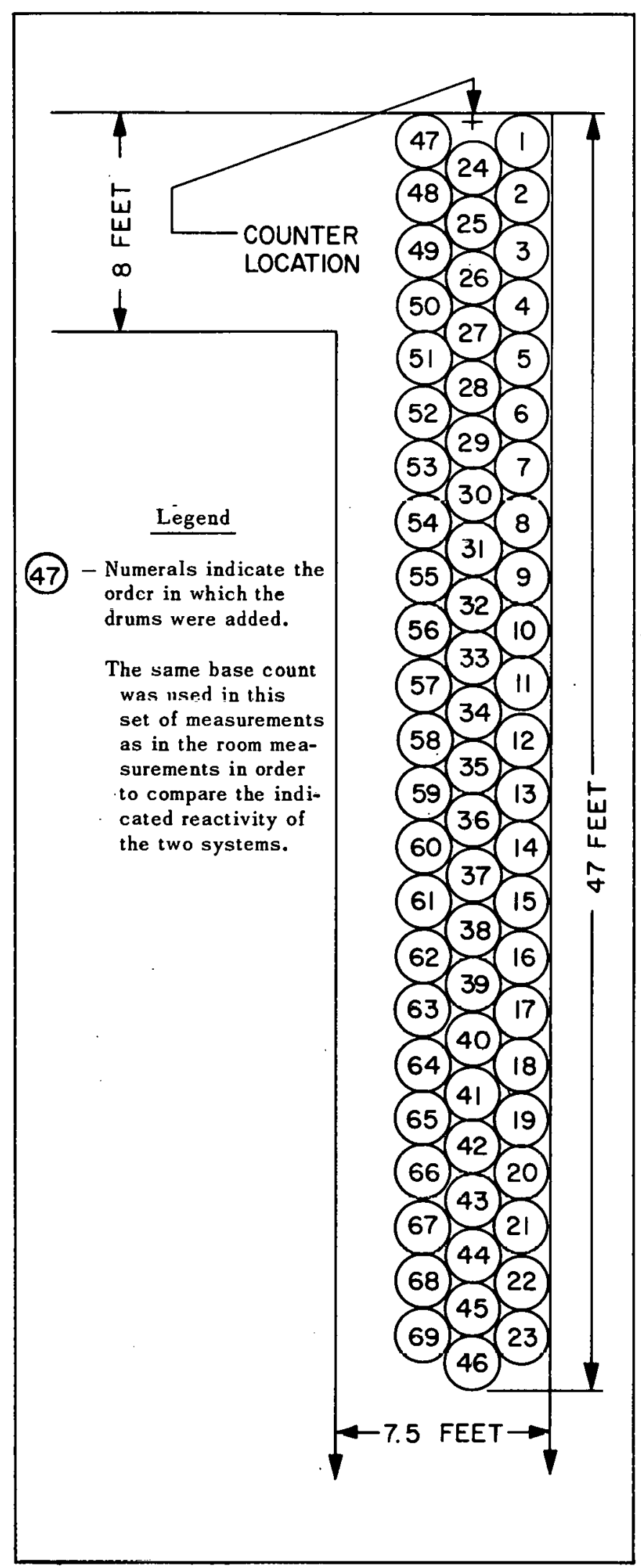

FIGURE 3. Diagram of Array Measurements in the Tunnel.
The dimensions of the tunnel permitted only 3 rows of drums stacked 2-layers high.

\section{RESULTS AND DATA}

Figures 4 and 5, respectively, are graphs of reciprocal multiplication data $(1 / M)$ versus total number of drums for planar, and 2-layer, hexagonal arrays. Extrapolations were made to the number of drums needed to fill the room.

Figure 6 is a graph of extrapolated values of $1 / M$ versus layers of drums stacked vertically. Each layer contained 97 drums which would completely fill a 15 by 25 -foot room. Clearly, for large arrays the drums could only be stacked two high, as a straight-line extrapolation of the data indicates 2.75 layers to be critical.

Figure 7 is a graph of measured values of $1 / M$ versus layers of drums in a critical array. The 7-, 19-, and 37-drum arrays are hexagonal in shape. The 46-drum array, which was the largest assembled, had drums added only to 3 sides of the 37-drum hexagon and was therefore not symmetric. Straightline extrapolations of $1 / M$ values show that the 19-drum hexagonal base extrapolated to 3.6 layers being critical and most nearly gives a cubic critical array, approximately 10 feet wide by 10 feet high.

\section{CONCLUSIONS}

The findings indicate that it was safe to more than double the present storage capabilities for plutonium ingots. The former mode of storage, which was calculationally based, called for only a planar rectangularly packed array of drums. The measurements demonstrated that a two-layer hexagonally packed array was subcritical. Consequently an increase was made in storage limits to a 2-wide by 2-high array of drums around the perimeter of a 15 by 25 -foot room and a 2 -wide by 2 -high array down the length of the connecting 225-foot tunnel with additional provision for pass-through of drums, past the existing array. 


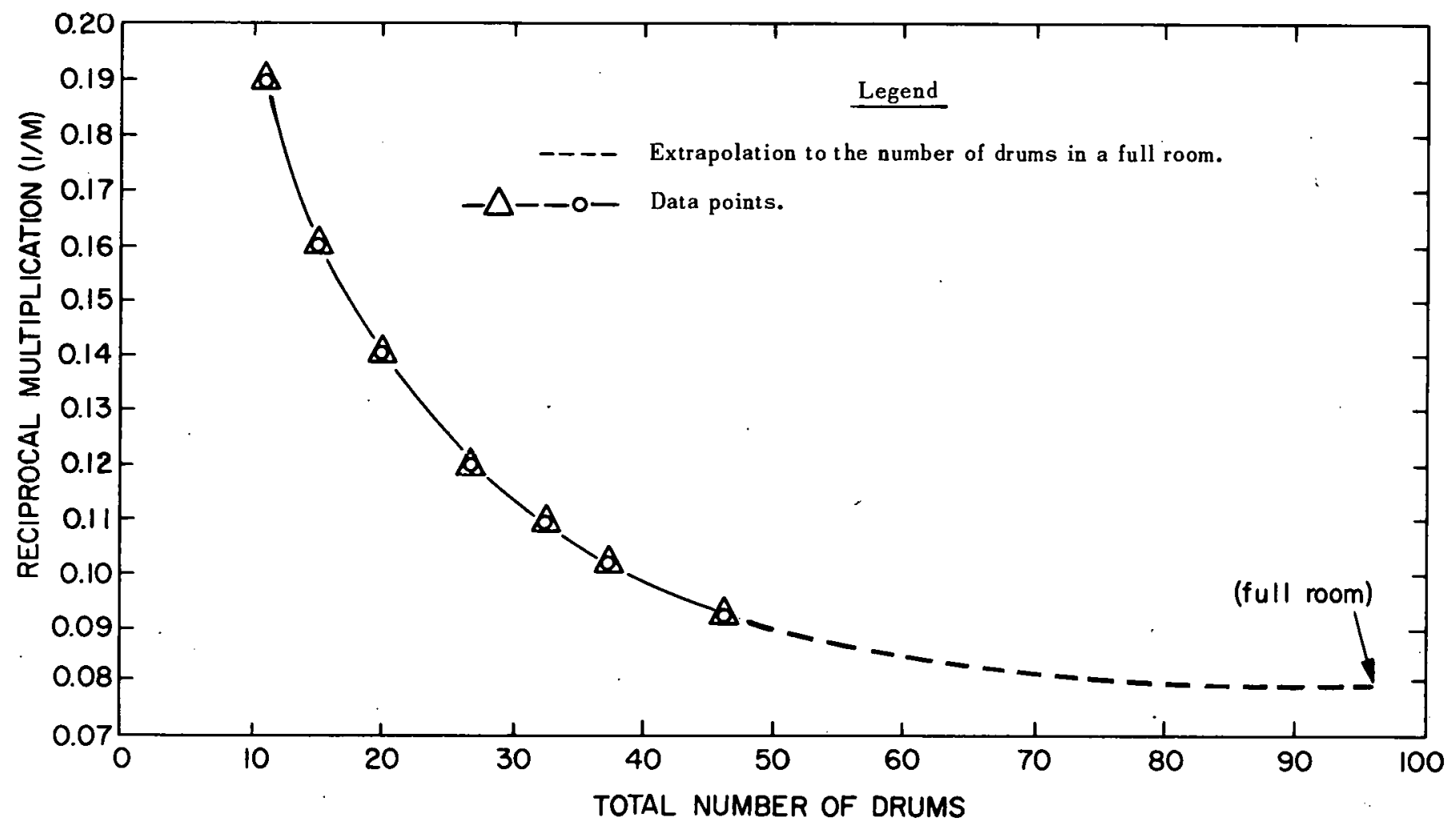

FIGURE 4. Hexagonal Close-Packed Planar Array of Drums.

FIGURE 5. Hexagonal Close-Packed Array of Drums Two Layers High.

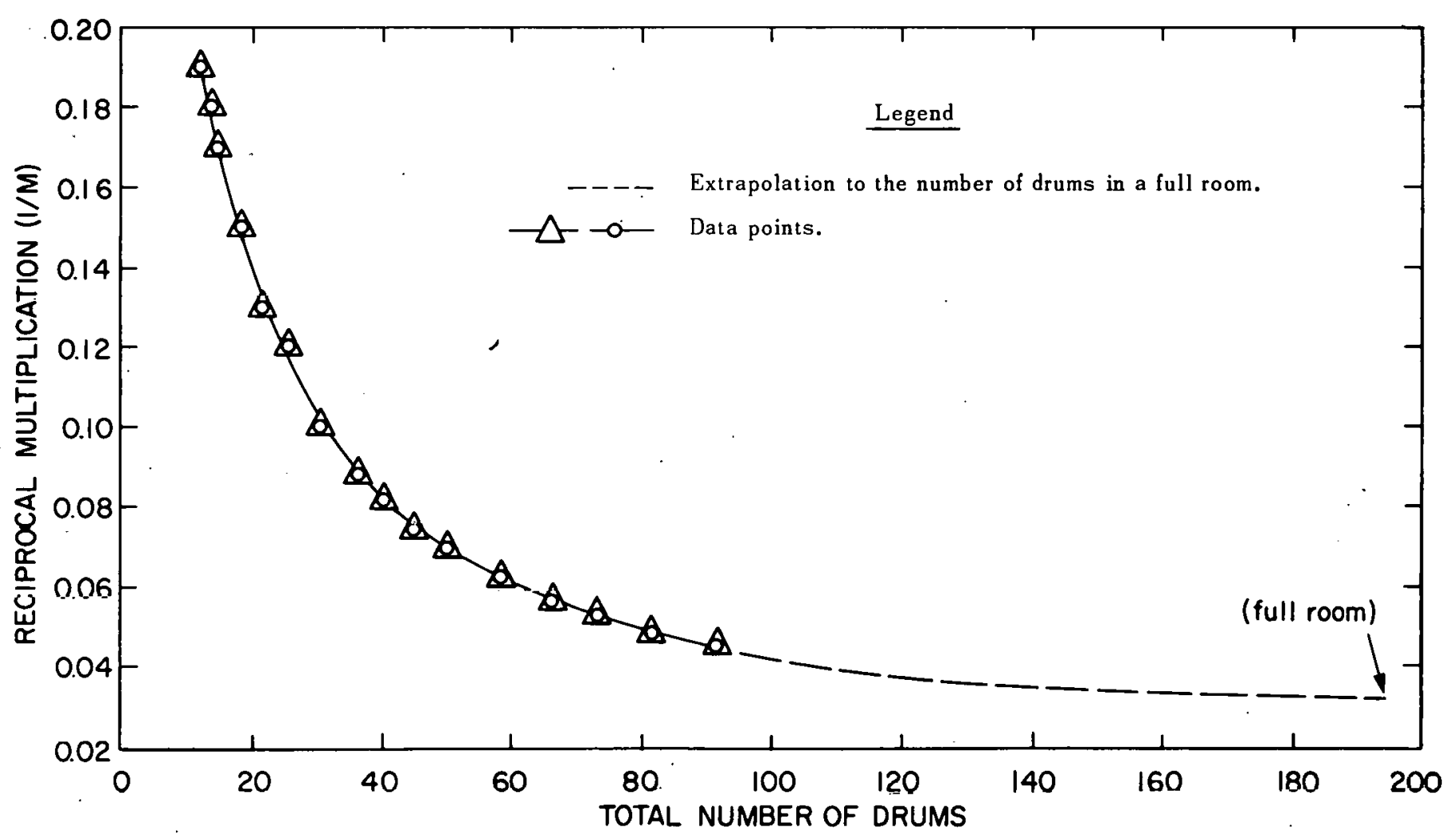


RFP-1242

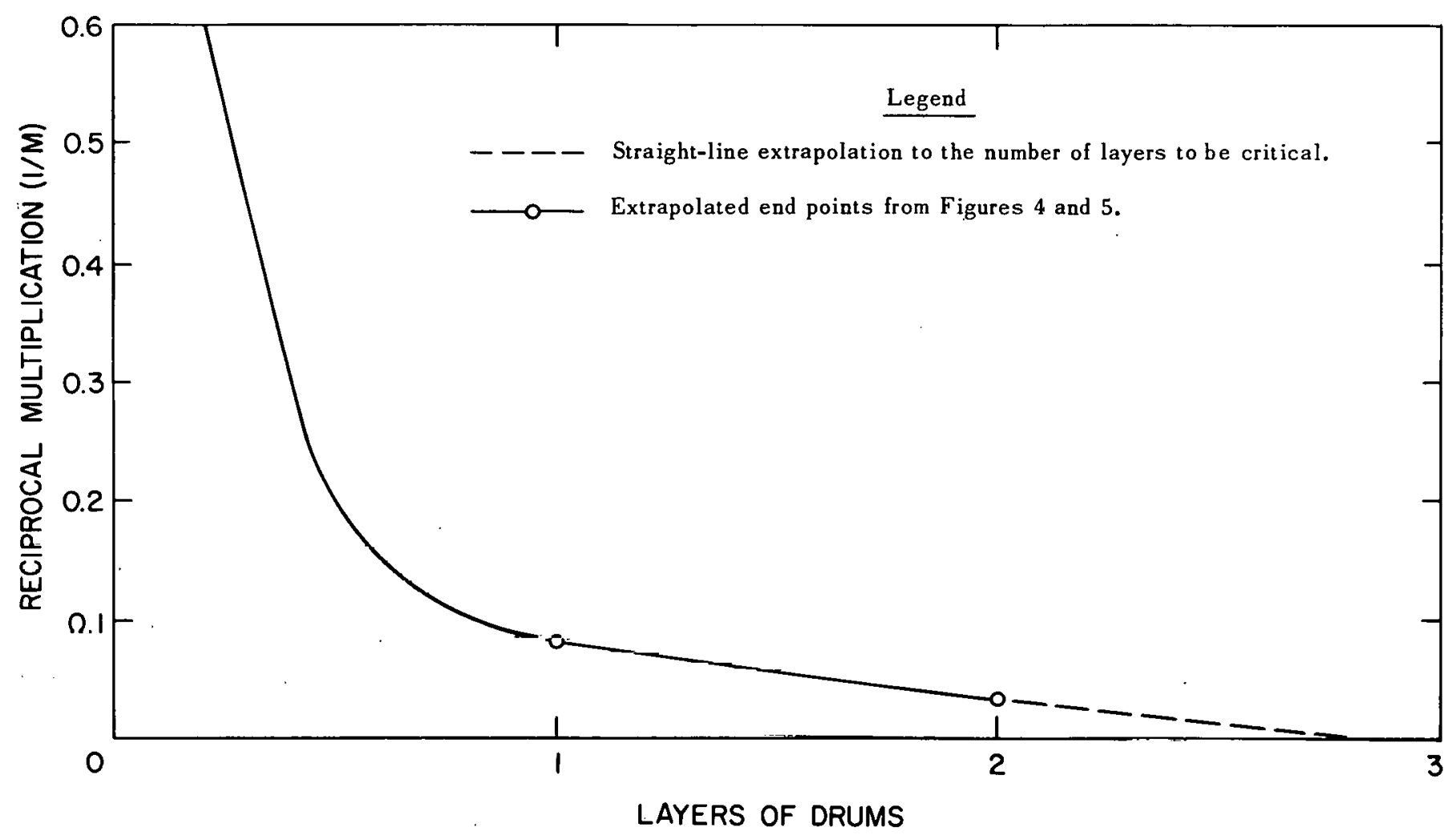

FIGURE 6. Critical Layers of a Hexagonal Close-Packed Array of Drums.

FIGURE 7. Number of Drums in a Symmetric Base.

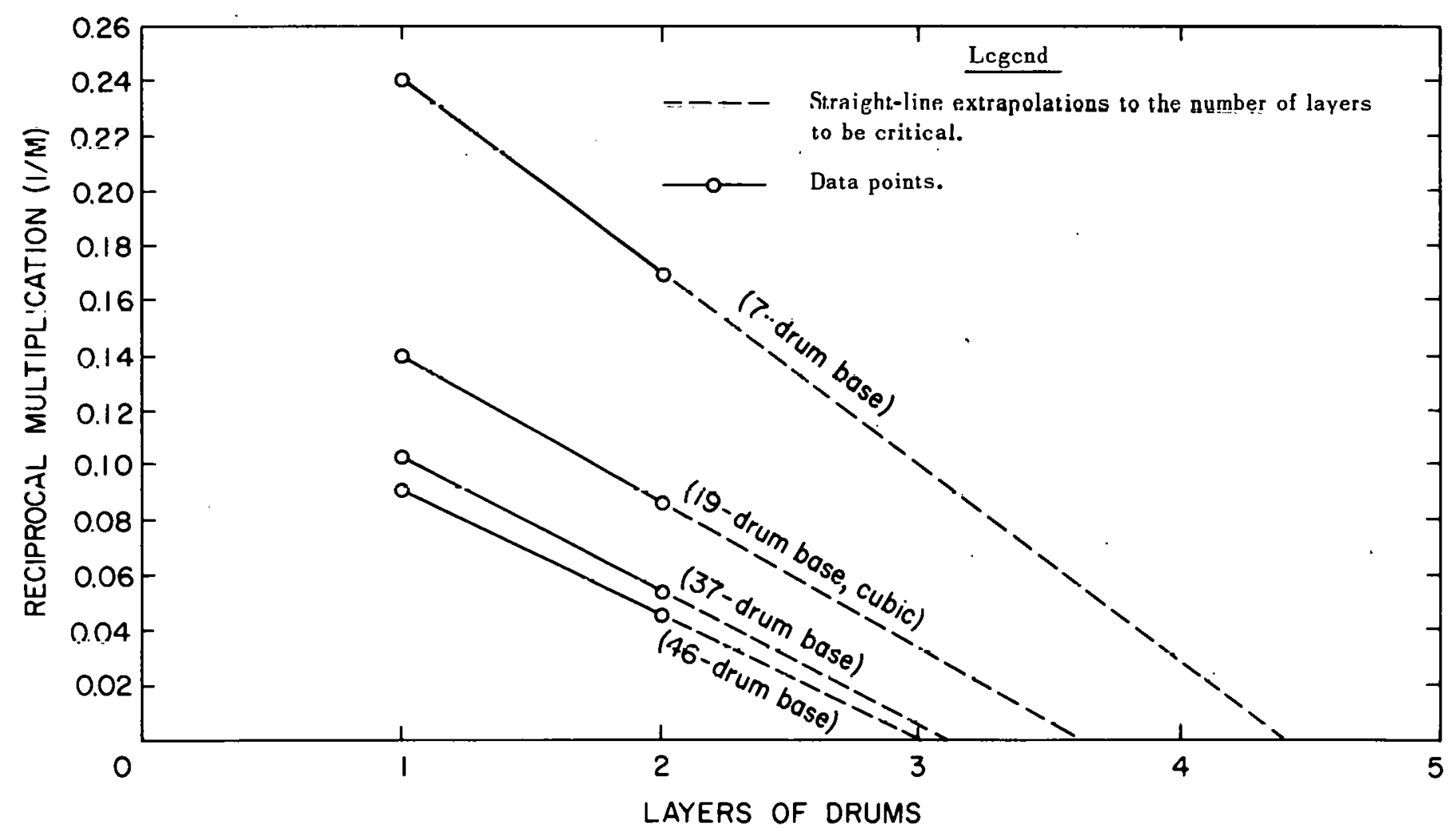

